\title{
13. Negotiating a religious identity in modern Japan: The Christian experience
}

\section{Colin Noble}

On the morning of 24 February, 1989, in freezing rain, a cavalcade of officers in military uniform accompanied the funeral cortege of the Shôwa Emperor (Hirohito) through the streets of Tokyo to the site of his funeral in Shinjuku Gyoen. The funeral was conducted in two parts - the first a brief religious ceremony performed by the emperor's family as a private rite of the imperial house, and the second an ostensibly non-religious one paid for by the Japanese government and attended by about 10000 invited guests, including numerous world leaders and representatives of foreign governments. The two ceremonies were differentiated by the presence of a curtain drawn to separate the secular space of the second ceremony from the religious inner sanctum of the first. This physical separation was a begrudging acknowledgement by the government of the notional separation of state and religion in the Japanese constitution drafted in 1946 during the Allied Occupation. ${ }^{\text {l }}$

Had the Japanese government had its way, the ceremonies would not have been divided. In the period following the emperor's death on 7 January, government spokesmen had repeatedly argued that performance of the two ceremonies in the same place and time was not in fact a breach of the constitution. The argument met with stiff opposition from a number of sources. Among these were numerous Christian voices. The stipulations in Article 20 of the constitution that the State and its organs shall refrain from...religious activity' and in Article 89 that 'no public money or other property shall be expended or appropriated for the use ... of any religious institution or association' remained a point of controversy in the ensuing 22 months until the completion of the rites of succession of the new emperor. $^{2}$

One scholar's suggestion that the controversy was 'largely orchestrated by

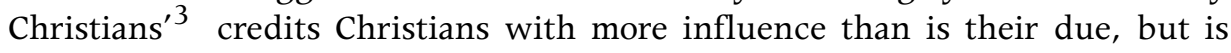
nevertheless helpful because it draws attention to two elements critical to this chapter. The first is the ineffectiveness of the Christian voice: despite the opposition, the two-part funeral ceremony still went ahead in one place, and was paid for with state funds, as were the subsequent succession rites of the following year. The second is that the ineffectiveness of the Christian-led opposition contrasts markedly with the influence Christians had in Japanese 
national politics earlier in the twentieth century. The Christian voice had not always been so devoid of political influence as it appeared in 1989-90.

The chapter follows the lead of sociologist John Clammer in asserting that the study of 'ethnically and linguistically entirely Japanese' minorities such as the Christian community 'throws considerable light on the mechanisms through which social exclusion is accomplished in Japanese culture and minority status is established and maintained. ${ }^{4}$ The point of departure from Clammer, though, is that the question addressed here is the path to political, rather than social, exclusions. Why has Christian political influence in Japan waxed and waned, but on the whole waned, over the course of the twentieth century? As the evidence presented below shows, the first third of the century was a period in which Christian influence was accepted as part of the national social and political fabric, to the point that Christian opposition to government legislative initiatives directed specifically at control of religions proved effective in preventing those initiatives from being implemented. This was not the case, however, in 1989. It is also clear from the evidence that the Christian community has throughout the second half of the century maintained a confrontational approach to the state despite changes in social and political circumstances over time.

The argument of this chapter is that this sustained confrontation has been an outcome of the attempt by Christians to negotiate a place for Christianity within Japanese society. Protestant Christian leaders were representatives of a newcomer on the religious scene in late nineteenth century Japan. They used confrontation with the state over legal definitions of religious behaviour as an avenue through which to carve out a political and social identity for the new religion. The legacy of the early years of Christianity in modern Japan remained at the end of the twentieth century as Christians continued to assert their right to be involved in negotiating the sacred. It is arguable that the decline in political influence has resulted, paradoxically, from this insistence on confrontation as the route to establishing a political identity within Japanese society.

\section{The post-war experience}

Two questions arise from the approach taken by Christians to the state in 1989-90. The first is why they chose such a confrontational approach. It is possible to argue for opposition to the state from biblical texts, but confrontation with the state is not an integral part of mainstream Christian thought. ${ }^{5}$ Nevertheless, the suggestion that Christians orchestrated the controversy of 1989-90 is understandable given the events of the late 1980s. It was clear from before the emperor died that Christians were not pulling any punches in the debate. In the last years of the Shôwa era, and particularly after the emperor's first major illness was announced in 1986, Christians broke social taboo in no uncertain terms by publishing numerous works which addressed the issue of an appropriate Christian response to the emperor's impending death. In 1988 
alone, for example, the following titles appeared from Christian publishing houses: Imperial Successions and Us; Imperial Funeral Rites; Thinking About X-Day [the day the emperor dies] Now; In Preparation for the Succession of the Emperor: What Should the Church Do? and From the Decision in the 'Nakaya Case' to the Succession of the Emperor. 6

The second question is why Christians opted to frame their critique of government involvement specifically in terms of the constitution. In answering questions about post-war Japan such as this, there is a temptation to seek answers only in the post-war period. And indeed, there are a number of features of post-war Japan which, in comparison with the pre-war period, made the job of challenging the state and the imperial system easier in 1989-90 than it had ever been. Among these must be counted several which will merely be mentioned in passing here in the interests of looking at more interesting features in depth. Freedom of religion was unconditionally guaranteed in the 1946 constitution (at least in terms of the letter of the law, although arguably not in its interpretation), whereas Article 28 of the previous 1889 constitution provided for only conditional freedom of religion. ${ }^{7} 1989$ marked the death of a controversial emperor, and the end of an era of controversy and qualified national success, in contrast to 1912 for example, which saw the death of a revered emperor and the end of an unparalleled positive period of Japanese history. By 1989 a Japanese Christian theology had emerged which was characterised by independence from foreign influence and reflective of its own history, in contrast to the early twentieth century, at which time the dominant theology was influenced strongly by social evolutionary theory and liberal interpretation of doctrine. Of more interest, though, are three other instrumental influences on the behaviour of Japanese Christians in the last years of the twentieth century: the structure and standing of the post-war legal system; the experience of public debate and confrontation with authority built up by Christians since the 1950s; and the issue of war guilt.

\section{The legal system}

Clearly without the post-war constitution's guarantee of freedom of religion, as well as of thought and conscience, of assembly and association, and of expression, ${ }^{8}$ things would have been different. The post-war church was free to criticise without fear of being shut down on the grounds that it was being either unlawful or disorderly, and Christians were also no longer open to the accusation on constitutional grounds that by questioning the actions of the emperor or the government they were neglecting their obligations as citizens. However, this alone cannot account for the church's vociferous opposition to the government's behaviour at the end of the 1980s, or for the fact that Christians have chosen to use the courts as a means of confronting the state in the second half of the twentieth century. 
In addition to the constitutional changes, there were also several changes after the war in the structure and social standing of the legal system that made it easier for Christians to pursue legal action than had previously been the case. A basic change to the Civil Code had been the introduction of adversarial procedures in which the onus was on plaintiffs to present their arguments forcefully, rather than on the judge to delve into the facts of the matter. Linked to this was the 1962 Administrative Litigation Procedure Law, which established three categories of administrative litigation, opening the way for 'protest litigation' (kôkoku soshô) ${ }^{9}$ as an avenue for action against the state. In particular, the law facilitated legal challenges to the constitutionality of state acts. The viability of constitutional review, argues Kyoto University's Taniguchi Yasuhei,

has brought about one major social change, a society has been developing in which the constitutionality of legislation and other State acts can be freely discussed before a court of law....one thing cannot be disputed: the new institution of administrative litigation has brought about a society in which an act of the administration can be attacked by the persons affected. ${ }^{10}$

Citizens have been able to take the state to lower courts over acts of the state they believe to be illegal, such as the use of public funds on religious activities.

In addition, the legal system has achieved a certain level of respectability in the eyes of the public that it did not have prior to the war. Taniguchi argues that in fact it was not until the late 1950s, when steps were taken to attract more capable people into the legal system, that more respect was accorded legal process and its outcomes. It was thus just as the legal system was achieving widespread respectability that Christians were first beginning to engage with the state through the courts.

Moreover, in addition to increased freedom of legal action and the respectability afforded such action, the likelihood of Christians tackling the Japanese government was arguably increased by the removal of two psychological barriers that stand in the way of litigants in Japan. ${ }^{11}$ Taniguchi argues that one psychological barrier to litigation is lowered when a grievance is shared by many people, and when the grievance can be directed at an impersonal body, such as a government department, rather than an individual, thus minimising the implication of direct confrontation. The introduction of protest litigation has allowed for the depersonalisation of the state, while the category of people's litigation has allowed for the initiation of legal proceedings on behalf of a group rather than just an individual. In summary, then, well before 1989, using the courts as a forum for resolving disputes had become both a respectable and an accessible avenue of political action. 
The rising respect accorded legal process was somewhat seductive to those seeking to justify their position through the courts. A positive outcome of a legal action would vindicate the position taken, require that the relevant action of the state be redressed, and lend credibility in the eyes of the wider public to the plaintiff's stance. Alternatively, though, a dismissal of the claims made would, in addition to establishing the basis on which the state could argue the legality of similar actions in the future, add weight to general public perception that the plaintiff had been out of step with accepted cultural norms in taking the state to task in the first place.

\section{Experience opposing the state}

It was against this backdrop that Christians built up a history of opposing the state in public debate over points of law and constitution in the decades preceding the death of the Shôwa Emperor. ${ }^{12}$ The most well-known legal battle, and the one which was to be adduced most frequently by the government in the debate of 1989-90, was the court case regarding the payment by Tsu City council of money to a Shinto priest for performing a Shinto ground breaking ceremony on the construction site of the City gymnasium in 1965. One key aspect of the Supreme Court decision in the Tsu City case was the introduction into the debate over the separation of state and religion of the term shakai tsûnen, which might be translated as 'social consensus'. The argument of the two-thirds majority of the panel of judges who upheld the constitutionality of the expenditure in their 1977 decision was that,

in considering whether or not a particular act constitutes 'religious activity' [the term used in Article 20 of the constitution]...we must judge objectively in accordance with the social consensus. ${ }^{13}$

The concept of 'social consensus' re-surfaced in the government's justification of its interpretation of the constitution in the debate over the nature and funding of the 1989-90 succession rites. ${ }^{14}$

The fact that the nature of 'social consensus' is not adequately defined partly accounts for the vigour with which the church debated the constitutional issue in 1989-90. The introduction into the debate of the notion of 'social consensus' in the Tsu City case was conducive to Christians' involvement in the later debate of 1989-90, because it gave them a particular issue on which they could legitimately challenge the prerogative of the state to pronounce judgment on religious behaviour. Paradoxically, although the focus on the concept of social consensus did liberate Christians to challenge the state, it also resulted in that challenge conforming to the mould of legal debate.

The question of 'social consensus' is also raised by anthropologist and missionary Robert Ramseyer in his discussion of yet another legal precedent on which 
Japanese Christians flexed their muscles prior to the succession debate. ${ }^{15} \mathrm{He}$ argues that in Japan individuals have come to accept myths about their society, some of which have been perpetuated in relation to the church-state issue. One instance of this was the most celebrated test case about freedom of religion, the Nakaya Case. The case was brought against the Self Defence Force, as an organ of the state, by the Christian widow of an officer who objected to her non-Christian husband's enshrinement as a war hero in the local Shinto shrine for the war dead. In this case the Supreme Court ultimately ruled in 1988 against the widow. The majority of the bench who voted for the ruling commented on the difference between Christians and Japanese, either inadvertently overlooking, or deliberately ignoring, the reality that the person on whom they passed judgment was both. ${ }^{16}$ The popular perception that being Christian and being Japanese were incompatible had now been given a legal stamp of approval by the Supreme Court. The newfound respect accorded legal institutions meant that the impact of decisions such as this was to sway public opinion generally, not just within the legal fraternity.

Both the Tsu and Nakaya cases came after the initial instance of clear confrontation between Christians and the government in post-war Japan. In 1955 the ruling Liberal Democratic Party (LDP) moved to establish a Constitutional Review Committee. This resulted in 1957 in a proposal to legislate for February 11 th to be declared National Foundation Day (Kenkoku kinenbi). In response, the United Church of Christ's Tokyo District Social Issues Committee raised a petition of protest containing 6000 signatures, and in 1962 the National Synod of the Church issued a counter declaration naming the date 'Defence of Religious Freedom Day', an appellation clearly hinging on the constitutional guarantee.

Roughly coincidental with this, a movement began directed at amending the status of Yasukuni Shrine, the central Shinto shrine in which war dead, including some convicted at the Tokyo war crimes trials, are enshrined. The intent of the movement was to have Yasukuni declared a non-religious entity, and thus make it eligible for government funding. An opposition movement also emerged, in 1959. The Yasukuni Shrine debate was to become the third major long-running and important debate over the separation of state and religion in which Christians, as well as other groups, developed their rationale and technique for the confrontation of 1989-90.

One of the noticeable features of the opposition to attempts to pass bills relating to Yasukuni Shrine was the cooperation between Christian and other groups. Opposition parties in parliament led the voices of protest when the first such bill was introduced in June 1969, while the Christian anti-Yasukuni movement held sit-ins, hunger strikes and rallies. By the end of the following month, 3.7 million signatures were on a petition against the nationalisation of the shrine. ${ }^{17}$ 
Christians worked alongside other dissident groups in opposing the bill, which was eventually laid to rest in 1974 after being presented to parliament five times. In July 1969 the National Christian Council, the All Japan Association of Buddhists and the Religious Federation of Japan, representing mainly new religions, issued a joint statement in response to the statement by Yasukuni officials that they would renounce their religious status immediately were the bill passed. By 1973, when the bill had been presented in parliament four more times, the opposition movement had embraced several Sect Shinto groups (i.e. those who dissociated themselves from the legally non-religious State Shinto) and newer Buddhist offshoots such as Rissho Koseikai. ${ }^{18}$ A key point, to which we return shortly, is that the ecumenical nature of the cooperation was reminiscent of the situation over 40 years earlier, when Christians opposing state legislative initiatives had been joined in the battle by other religious groups.

But let us return now to the issue of the 1989-90 succession rites. We can trace a line from the Supreme Court split decision to uphold the constitutionality of the payment by Tsu City of money to a Shinto priest, through the Yasukuni shrine nationalisation debate and the Nakaya case, to the debate in question. As noted above, the 'social consensus' legal precedent set in the Tsu case was used by the government, which argued that there was a consensus that the ceremonial procedures should take place in line with 'the traditions of the imperial household' (kôshitsu dentô). Awareness of the concept of social consensus enabled church leaders to engage in debate, as typified by United Church of Christ leader Tomura Masahiro, who points out that what effectively happened was that 'social consensus' (shakai tsûnen) became elevated to 'state consensus' (kokka tsûnen). ${ }^{19}$ In essence, however, the Supreme Court had already decreed the definition of social consensus. The accepted understanding was that Shinto ground breaking ceremonies were not religious, and that Christians and Japanese were different. Thus, Tomura's insistence that there is a qualitative difference between a ground breaking ceremony and an imperial succession carried little weight. Arguing this particular point is an example of the way in which the church's political involvement was shaped, to its detriment, by its prior experience.

The point to note here is that the momentum begun in the 1950s carried over into the following decades. Although the battle over the Yasukuni Shrine bills, unlike the Tsu City and Nakaya cases, was fought in the national assembly rather than the courts, it really provided the psychological groundwork, as well as some political and legal experience, for later court cases. A movement called Christians for Defence of the Constitution ${ }^{20}$ was begun in 1962 in the wake of the renewal of the US-Japan Security Treaty. Its members 'were active in the Nakaya case, the litigation against the constitutionality of the Tsu City groundbreaking ceremony, and the opposition to the official visits by cabinet and members of parliament to Yasukuni Shrine...and became the driving force 
in the opposition to unconstitutional national policies.'21 The fact that, particularly on the Yasukuni issue, Christian opposition was echoed by many sectors of society lent to Christians the sense that they did not stand alone in their opposition to state acts, and that the government could be tackled without undue concern about direct personal confrontation with any individual representing the government.

\section{Guilt}

A third critical component in the post-war Christian experience is the impact of the ongoing process of reflection by Japanese Christians on the role they played in complying with the militarist regime of the 1930s and 1940s. Immediately after the war, widely respected Christian leader Kagawa Toyohiko called for repentance, $^{22}$ but the first significant institutional admission of guilt was the Confession of Responsibility During World War Two issued in 1967 by the United Church of Christ in Japan, the remaining core of the combined Protestant church compelled into existence by the Religious Organisations Law of 1939. This was but the first of what has since become a torrent of such statements, a torrent which has included more recently an apology from Japanese Christians to the people of Asia (1990), a Japan Evangelical Association apology for supporting Japan's invasion of Asian countries (1995), and even an apology from the Holiness group of churches (1995), which might well be justified if they felt they had nothing for which to apologise, since they stood out during the war years for their opposition to the state and consequent persecution at the hands of the government.

The fact that the issue of war guilt was not formally addressed by the largest denomination in Japan until 1967, a full generation after the end of the war, is a key to understanding the relationship between church and state in the later post-war years. Why was there such a delay? In general, the Japanese church in the immediate post-war period was viewed extremely positively by non-Christians. The acceptability of Christianity was sustained by a combination of factors which could be summed up in terms of Christians having shared two significant experiences with all other Japanese: suffering under repression in the 1930s and 1940s, and the struggle for reconstruction after the war. 'The positive public image of the church at the end of the war had the effect of numbing the church to its wartime responsibilities. In a sense the church indulged itself in the limelight and capitalised on the opportunity. Of course, one could understand the church's desire to evangelise. However, the lack of reflection and repentance ${ }^{23}$ left unanswered the question of the appropriate relationship between church and state. And that was the question which still faced the Japanese church at the end of the 1980s. 


\section{A trans-war perspective}

The fact that there were significant elements in the Christian experience in post-war Japan which were absent before the war seems to suggest that the late twentieth century church-state confrontation is explicable as a purely post-war phenomenon. However, investigation of the pre-war period reveals that the confrontation of the late twentieth century exhibited an essential continuity with the Christian experience of particularly the 1920s and 1930s.

\section{Early background}

Scholars of various disciplines and writers exhibiting a range of objectives for writing seem united in their understanding that by the time Protestant Christianity arrived in 1859 there was a well established practice in Japan of religion being used by the state to further its own purposes, and that this was generally not considered remarkable. Such a situation presents a clear contrast with the insistence on separation of state and religion in the United States, the cradle of much of the Christianity that reached Japan in the nineteenth century. Nevertheless, Japan's first modern constitution, promulgated in 1889, included a stipulation of religious freedom, albeit with restrictions. Article 28 of that constitution stated that the freedom of religion of Japanese citizens was conditional upon it being 'limited to the extent that it does not hinder law and order, and does not oppose the duties of citizens.' This was the bedrock legal principle on which the government's treatment of religions rested until 1945. As the government's definition of law and order, and its idea of the duties of citizens, became more and more restrictive, so too did its treatment of religious groups.

According to the Japanese government's own analysis, 1899 marked a turning point in its treatment of Christianity. From the removal of the prohibition of Christianity on 2 June 1873 until 1899, the government approach had been to give tacit permission for Christianity to expand, even though it had no official status as a religion. ${ }^{24}$ December 1899 saw the first attempt to introduce legislation specifically pertaining to religious organisations. ${ }^{25}$ The government expected resistance to the bill. To lay the groundwork, several months before the bill was put to parliament, it issued a combination of sub-legislative regulations, which it insisted were required to enable it to bring Christianity adequately under the umbrella of Japanese law and offer Christianity the same legal protections enjoyed by Buddhism and Shinto shrines. ${ }^{26}$ The aggregate effect of these initiatives of 1899 was to hold out to the Christian community the carrot of equality with other religions in Japan, in return for the right to use the stick of legislation to keep Christianity, and Christian schools in particular, in line with government preferences. The Christian reaction was to accept the carrot, but resist the use of the stick. At a later point in time, hunger for the carrot would fuel acceptance of the stick, but at this point the result was strident opposition to the bill put 
to parliament in December of 1899. In contrast to the futility of the Christian voice 90 years later, that opposition was ultimately successful.

\section{0-26}

The picture that emerges from early twentieth century events is of a Christianity which has had a long held ambition fulfilled. Evidence abounds of the Christian desire for acceptance by mainstream Japanese society from at least as early as the 1870s. Notwithstanding the defeat of the 1899 bill, the other ordinances enacted in 1899 essentially meant that Christianity had now been granted official equality with other religions, and it used its newly acquired status to resist attempts by the state to control it. The successful defeat of the 1899 bill was early evidence that Christians now had significant social and political influence.

At least on the surface, Christianity was given tacit support from government sources in the early years of the new century. When the Tokyo venue for the Eighth International Sunday Schools Convention was destroyed by fire in 1908, for example, business leaders and the government contributed to restoration costs, and more interestingly, so did the imperial household. In 1909, when the Protestant Christian churches held a week long conference in Kanda, a central suburb of Tokyo, to celebrate fifty years of Protestant missions in Japan, they received congratulatory letters from the Prime Minister, the Minister of Education, the governor of Tokyo Prefecture, and the Mayor of Tokyo. Christianity's political status seemed in some ways on a par with Buddhism and Shinto, with representatives of all three being asked for input into government decision making processes. In 1912 the Home Ministry invited all three to what came to be known as the Three Religions Conference, at which the Minister sought their opinions on the best means for promoting the morals of the people. Christians were included again in discussions with the Prime Minister about the best way to instil enthusiasm in people after World War One in 1919, and about how to improve the thinking of the nation in 1924. It is clear that in the second and third decades of the twentieth century, the Christian church was well accepted within the power structures of Japan, even though individual Christians may have felt singled out for criticism of their stance on certain issues. ${ }^{27}$

The responses of the church to the 1912 Meiji-Taishô and 1926 Taishô-Shôwa successions further indicate the extent to which Christianity had become entwined in the power structures of the time. Dohi and Tomura record in detail the initial reactions of the churches to the news from the then Imperial Household Ministry in July 1912 that the Meiji emperor was seriously ill. ${ }^{28}$ The Alliance of Christian Churches of Japan (ACCJ), the umbrella Christian organisation of the time, immediately sent two representatives, including essentially conservative evangelical Kozaki Hiromichi (1856-1928), to the ministry to pay respects. It also issued a call for all churches in the Tokyo area to hold meetings to pray for the emperor's recovery, and these were followed by larger combined gatherings 
of churches, with all centers reporting 'good attendances, given that it is summer'. ${ }^{29}$ The non-Japanese Episcopalian Bishop of North Tokyo drew heavily on the Church of England Prayer Book prayers for the occasion of a death in the royal family to pen a special prayer which gave thanks for the blessings of the years of the emperor's reign before asking that 'prayers of loyalty' for the emperor's recovery be heard. ${ }^{30}$

In short, the reaction of institutionalised Christianity was indistinguishable from that of the rest of society. In fact, so enamoured were the churches with the emperor, that they requested the government to allow Christian representatives to attend the emperor's funeral in September 1912. That the church was seen as acceptable by the government of the day is attested by the fact that not only were 150 Christian representatives permitted to participate in the large ceremony in Hibiya Park, but seven were included in the much smaller group within the temporarily constructed funeral building. Even Uchimura Kanzô (1861-1930), the outspoken leader of the non-church movement and object of censure for his refusal to bow to the 1890 Imperial Rescript on Education which demanded loyalty to the emperor, expressed his sadness at the passing of the emperor by suggesting that this was the type of situation referred to by Old Testament prophet Joel's prophetic description of the day when 'The sun and the moon are darkened, and the stars withdraw their shining' (Joel 3:15). ${ }^{31}$

When the Taishô emperor died in 1926, he happened to do so on 25 December. One would expect that the fact that the death occurred on such an important day in the Christian year would have produced unavoidable conflict with Christian activities. However, if anything the churches in 1926-28 altered their own agendas to support the imperial institution and the government's actions to an even greater extent than they did in 1912-14. Christian representatives were again sent to the palace to inquire after the emperor's health in the days leading up to his death, and Christians again attended the emperor's funeral, although on this occasion their request to attend the smaller private ceremony was denied. The church went beyond its level of support in 1912-14 by issuing a statement, at the October 1928 Conference of the Christian Churches, which congratulated the Shôwa emperor on his ascension to the throne. ${ }^{32}$

\section{$1927-29$}

By the end of the 1920s, then, it appears that the church in Japan had moved 180 degrees from its 1899 opposition to the state's attempt to legislate for control over religious organisations. The state had supported the church, and the church was reciprocating by overtly identifying with the state. The events of 1927-29, however, mark a second turning point after 1899 in the relationship between Christians and the state. 
In 1927 the Wakatsuki government attempted again to pass a Religions bill, and yet again was unsuccessful. Opposition came from Christians as well as other religious groups. In fact, to judge by the headlines in editorials of the major newspapers, the opposition did not appear to be limited to religious groups. ${ }^{33}$ The situation in 1927 was more complicated than that of 1899. In June 1926 the government had decreed the establishment of the Religious Structures Investigative Committee. The Committee was charged with drafting a Religions bill, which it duly did, and the bill was submitted to the January 1927 session of parliament. Members of major religions, including Christianity, were included among the 40 members of the Committee. In that sense, the situation had changed little from the Three Religions Conference of 1912. Christians were still among the privileged few religious groups given a role in shaping government policy. 1927, though, sees the beginning of the souring of state-Christian relations. And it is only after the relationship sours that the mood of legislation also begins to display an ominous tone as far as Christians are concerned. The government's fundamental position was that the 1927 bill was redressing an enduring oversight on their part. Here was Christianity, recognised as a religious group other than Shinto and Buddhism for almost 30 years since Ordinance 41 of 1899, yet unlike those two, it was not protected adequately by legislation pertaining to religions.

The government argued on a number of grounds that Christians ought to embrace the bill. The lack of legal certainty for Christianity was a problem; all 56 branches of Buddhism and 13 schools of Shinto had agreed to treat Christianity as equals; and any attempt to differ in the treatment of Christianity was morally reprehensible. The government rebuttal of suggestions that Christianity be treated differently is worth quoting at length not only because of the content, but because the savagely sarcastic tone of the response indicates just how far the government had moved in the 15 years since it deemed Christianity worthy of a seat at the policy planning table.

Surprisingly, in response to the Religious Bodies Law, the basis of which is equality of the three religions of Shinto, Buddhism and Christianity, arguments have emerged, albeit an extremely small number, that Christianity ought to be segregated and excluded.... The second [of three arguments] is the movement among a number of Christians which in general terms is intent on rejecting even the laws required by the state as the foundation of the freedom of religious groups....[Theirs] is an unfair perspective that seeks to enjoy special freedoms for themselves only, leaving Shinto and Buddhism in their present state constrained by the existing laws and ordinances. It's unfair because, if, as this one faction of Christianity intends, the Religious Bodies Law were to be defeated, the laws and ordinances that have for several decades since the beginning of the Meiji period pertained to Shinto and Buddhism will remain 
unchanged, and Christianity alone will be governed by Ministry of Home Affairs Ordinance 41 of 1899 relating to religions other than Shinto and Buddhism. If the opinion had been premised on an absolutely fair and just starting point, there is no way it would be simply a refusal to accept the Religious Bodies Law. It is entirely reasonable that there are those who criticize it as a movement very much degenerated into self-centred egotism. ${ }^{34}$

The implication is clear. Christians who make this sort of claim are interested only in their own welfare. Not only are they no longer suitable recipients of invitations to confer with policy makers, but the religion they espouse is not likely to have anything to contribute to the good of the nation. In the political climate of the late 1920s, as the democratic ideals of the Taisho era were increasingly subjugated to the coercive force of a state apparatus buttressed by the 1925 revised Peace Preservation Law, the message was clearly not just addressed to Christians informing them that the government considered their stance unacceptable. It also sounded a warning bell to other dissident voices that they, too, would be pilloried by the government if they were to step out of line. In the same document the government was equally scathing of the Buddhist voices who argued for continuation of the separate treatment of Christianity, pointing out that they came from 'a small portion of Buddhists who advocate absolute belief and narrow-mindedly posit the same old intolerant argument for discriminatory treatment of Christianity.' 35

Clearly, there is little government love lost for Christianity. But the point to note here is that the ridicule was mutual. In light of the nature of the proposed legislation, the long sought after equality with other religions now became unpalatable to Christians, and the vituperative language cited above came after attacks by Christians on the Religious Bodies bill and its drafters. Some of the language used by Christians to attack the bill could at best be described as uncharitable, and is probably more accurately described as provocative. It is the language of personal invective. Uchimura Kanzô, for example, one of the elder statesmen of Japanese Christianity, asserted that the interference of politics in religion was 'foolish'. In particular, the Ministry's suggestion that those opposing the bill are ignorant of the nature of religion is a response to Uchimura's claim that,

the people who drafted it [the bill] don't know a thing about religion. In my nearly 40 years of ministry, I have hardly ever met a bureaucrat or politician who knows anything about religion... [the drafters] are just outsiders who know nothing of God, spiritual matters, and the world to come. $^{36}$ 
Uchimura's words could hardly have been more inflammatory when we remember that the committee that drafted the bill included Christian members.

In 1929 the government again tried to pass legislation controlling religious activity. In response, the churches in Japan set up an ecumenical special committee to respond to the Religious Bodies Bill ${ }^{37}$ under the chairmanship of Yamamoto Hideteru, retired professor of church history at Meiji Gakuin. At the peak of the debate in February-March 1929 the committee investigated the attitude of 1240 Protestant churches and reported that in a limited period since the bill had been tabled, over two thirds (865) had registered their opposition to the bill. ${ }^{38}$ The special committee concluded that the Ministry of Education says that the majority of churches support the proposed bill, with those opposing being but a few, but that is totally incorrect ${ }^{\prime} .{ }^{39}$

\section{The 1930s}

Within the space of less than two decades from the time Christian leaders had sat down with government leaders to address the declining moral state of the nation, and no more than three years after churches had endorsed rites of imperial succession, the church-state relationship had clearly become a confrontational one. But it was not only the state that Christians had now begun to alienate. Well before 1939, and even before Japan became seriously embroiled in conflict with China in 1937, the social context of legislation had changed in an important way. In 1899 and again in 1927, Christians had stood alongside spokespeople of other religions in opposing the government's legislative initiative. By as early as 1933, however, the Buddhist Association had decided that equating Christianity with Buddhism was not to their liking. De facto, the position they took was that of the government:

Today, the changes and rumblings in the world of religion have become more violent. This is a point in time when we feel more than ever the urgency of boosting the spirit of the people...We believe that it is a matter of the utmost urgency that...religions be given their appropriate place in terms of the law. 40

Six years later, under Prime Minister Hiranuma in January 1939, by which time domestic and international circumstances had changed dramatically, the government again put to the parliament a Religious Bodies bill. This time the bill was more succinct, simplified to just 37 clauses from the 130 of the 1927 Religions bill. Shinto had been excluded as a religious group, whereas the 1927 Religions bill had included, in addition to one chapter each on Shinto and Buddhism, a third on Christianity. The bill was passed on March 23, without dissent from inside the chamber or on the streets, ${ }^{41}$ and promulgated the following month. The voice of opposition had faded. On the contrary, in 
Christian circles, there was rejoicing that the word 'Christianity' appeared for the first time [in a bill passed into law] as a religious body'. ${ }^{4}$

To suggest that the spectre of the repressive military regime accounts for the neutralisation of Christian opposition to legislation which was unchanged in essence from that of a decade earlier is too simplistic. The argument of this chapter is that the deafening silence was as much of the Christians' own volition as enforced by the government of the day. Christians' eagerness to celebrate the recognition Christianity had been given as equal in social and legal status to the other two religions of Buddhism and Shinto, had blinded them to reality. And the reality was that by at last succeeding in placing Christianity on a par with other religions, the government had managed to position it to be shaped to the government's liking.

The government was able to use the confrontational approach taken by Christians to further isolate the Christian voice from the position of political influence it had held only 15 years earlier. Akiko Minato's suggestion that 1912 marked the height of Christian acquiescence to the government of the day clearly needs to be rethought. ${ }^{43} 1912$ may well have marked the high water in terms of Christian political influence, but 1939 and the ensuing years saw far greater cooperation with the government than thirty years earlier. Analysis of the post-war Christian experience suggests that Christians had failed to learn that acceptance by the wider society comes at a price, and that by becoming incorporated as part of the state apparatus in the 1910s and 1920s, Christians had left themselves with little room to manoeuvre in opposition to the state in the 1930s.

\section{Conclusion}

We thus observe a seesaw of church-state relations in the pre-war era which is repeated in the post-war period. In the mid-nineteenth century missionaries with notions of religion free from state interference arrived in a society where state use of religion was the centuries-old norm and Christianity had been outlawed for over 200 years. The uneasy relationship came to a head in the confrontation of 1899, only for the tension to dissipate in the mutual recognition of the 1910s and 1920s. Confrontation again becomes the key characteristic of the relationship from 1927 through the 1930s and 1940s, before the halcyon days of the Occupation in 1945-52. The post-Occupation period sees a reversion to the type of confrontation on the legal battle field which marked the late 1920s and 1930s.

How do we account for this seesaw of church-state relations? State policy alone is a partial but ultimately inadequate explanation. More fruitful is an understanding from the point of view of Christian identity.

The sense of guilt at both wartime acquiescence and post-war tardiness in admitting guilt, combined with the knowledge that their actions would be subject 
to the scrutiny of society around them, ensured that Japanese churches in 1989 did not want to be seen to be repeating their error of earlier periods. They were prepared to go on the political offensive as publicly as possible. In their desire to be seen to do the right thing, Japanese Christians succumbed to the temptation to engage in the constitutional debate at the expense of presenting a more identifiably Christian position. The home ground advantage had been ceded to the state, and it appears that on its own turf the state presented as an invincible opponent.

The presence of a guilty conscience for having cooperated with the war effort was a new element in the political awareness of the post-war Japanese church. Had Japanese Christians' awareness of their own history, an awareness which Yasuo Furuya identifies as arising in the $1970 s,{ }^{44}$ led to greater consideration of events a little further back than the late 1930s, there is reason to think that the pre-war pattern of legal confrontation might not have recurred. The reality, however, appears to be that the issue of war guilt so dominated Christian historical consciousness that determination to ensure that the mistake of acquiescence to the state was not repeated became the paramount guide to behaviour.

Opposition to the state became a public platform in the 1970s and 1980s on which the churches could establish their credentials as no longer being tied to the state. Such opposition had several characteristics: it was public; it was intellectual; it ostensibly addressed the question of war guilt; and it maintained a sense of separation or purity. On all these counts, I would suggest that the church was out of step with the rest of Japanese society. Moreover, it chose the political realm, about which increasingly consumerist and materialist Japan cared little in the 1970s and 1980s, as the forum for asserting its influence. The church focused on sustaining its identity as Other than the surrounding society, and chose to do so by declaring its opposition to the state. It worked from an assumption of cultures as static, discrete and singular, rather than fluid, not clearly defined, and multi-faceted. ${ }^{45}$

In essence the point to realise here is that the Christian community in Japan in the post-war period seemed to have learnt little from its previous experience. Firstly, it emulated the nineteenth-century missionary insistence on self-separation from surrounding culture. Secondly, it imitated its own ultimately futile course of opposition to legislation of religion in the 1920s and 1930s. Thirdly, it adopted the pattern of using the post-war constitution as the basis for arguing against government initiatives. In doing so, it conceptually locked itself into the government's sphere of influence, just as it had wedded itself to the state more overtly in the 1910s and 1920s.

The Christian opposition to state attempts to legislate for control over religion in the 1920s and 1930s was a critical turning point in the relationship between 
church and state. The halcyon days of the immediate post-war period appear at first glance to indicate a return of Christianity to a privileged position comparable to that enjoyed forty years earlier. Analysis shows, however, that the position rested on the shifting sands of constitutional guarantees, a willingness to avoid discussion of past mistakes, and short-lived goodwill engendered by shared hardship during the war and reconstruction period. The re-emergence in the 1960s and beyond of the issue of the relationship between church and state, and particularly attempts to introduce legislation in that area, resulted in the church moving even further towards sustaining its identity by maintaining its distance from societal norms. Opposition to the state became the predominant mode of self-expression of the Christian identity to the surrounding society.

Seduced by the freedoms enshrined in the post-war Japanese constitution, Christians used it as the bedrock of their self-identity. They attempted to define and sustain an identity by using an institution of the state. By doing so it seems that they came perilously close to losing sight of both previous Japanese Christian experience and broader Christian history. As such, their experience offers a contemporary case study that appears to confirm the wisdom of the biblical injunction to eschew conformity with surrounding societal norms (Romans 12:2), lest one's Christian identity lose any distinctively Christian characteristics.

\section{ENDNOTES}

1 The two relevant articles of the Constitution are Articles 20 and 89. Article 20 reads: 'Freedom of religion is guaranteed to all. No religious organization shall receive any privileges from the State, nor exercise any political authority. 2) No person shall be compelled to take part in any religious acts, celebration, rite or practice. 3) The State and its organs shall refrain from religious education or any other religious activity.' Article 89 reads: No public money or other property shall be expended or appropriated for the use, benefit or maintenance of any religious institution or association, or for any charitable, educational or benevolent enterprises not under the control of public authority.'

2 The succession was completed with ascension rites in November 1990, which likewise consisted of two parts, although unlike the two parts of the funeral, which occurred on the same day, these two were separated by ten days. The first was the sokuinorei, or ascension itself, a public declaration of succession to the throne by the new emperor, and the second was the most contentious of all the ceremonies involved in the succession process, the daijôsai, or grand harvest festival.

3 Clammer, John 2001, Japan and its Others: Globalisation, Difference and the Critique of Modernity, Melbourne, Trans Pacific Press, p. 168.

4 Clammer, John 1997, 'Sustaining otherness: self, nature and ancestralism among contemporary Japanese Christians', Japan Forum, vol. 9, no. 2, p. 179.

5 The most widely adduced New Testament point of reference in support of obedience to the state is Romans 13:1-7; justification for opposing the state is derived primarily from Acts 4:19 and 5:29. Relevant Old Testament sources include the warnings about the demands of civil authorities in 1 Samuel 8:1017 , and the altercations between Israelite rulers and religious spokesmen recorded in the pre- and postexilic literature. For an introduction to some of the key thinkers on church-state relations, see VillaVicencio, Charles (ed.) 1986, Between Christ and Caesar: Classical and Contemporary Texts on Church and State, Grand Rapids, Eerdmans.

6 Dohi, Akio and Tomura, Masahiro (eds) 1988, Tennô no daikawari to watashitachi (Imperial successions and us), Tokyo, Nihon Kirisutokyôdan Shuppankyoku; Sasagawa,Norikatsu 1988, Tennô no sôgi (Imperial Funeral Rites), Tokyo, Shinkyô Shuppansha; Tomura, Masahiro 1988, Ima, X-dê o kangaeru (Thinking about X-Day Now), Tokyo, Kirisuto Shinbunsha; The Japan Baptist Convention, 1988a, Tennô no daikawari ni sonaete: sonotoki kyôkai wa...(In Preparation for the Succession of the Emperor: What should the Church 
do?), Tokyo, The Japan Baptist Convention; The Japan Baptist Convention 1988b, 'Nakaya saiban' hanketsu kara tennôdaikawari e (From the Decision in the 'Nakaya Case' to the Succession of the Emperor), Tokyo, The Japan Baptist Convention.

7 The condition was that religious freedom was 'limited to the extent that it does not hinder law and order, and does not oppose the duties of citizens.'

8 See Articles 19 and 21 of the Constitution.

9 Note that the translation 'attacking action' is also used for example by Taniguchi, Yasuhei 'The PostWar Court System as an Instrument for Social Change', DeVos, George (ed.) 1984, Institutions for Change in Japanese Society, Berkeley, CA, University of California, p. 32. The other two categories are 'party litigation' (tôjisha soshô ) and 'people's litigation' (minshû soshô ).

10 Taniguchi, 1984, pp. 37-8.

11 Taniguchi suggests several psychological barriers to litigation in Japan — see Taniguchi, 1984, p. 34. The suggestion that Japanese are inherently less litigious than other nations has been well refuted. See, for example, Haley, John O. 1978, 'The Myth of the Reluctant Litigant', Journal of Japanese Studies, vol. 4, no. 2, pp. 345-70.

12 For a reasonably comprehensive introduction to several major legal and political issues in Japan in the 1960-80s, see Field, Norma 1993, In the Realm of a Dying Emperor: Japan at Century's End, New York, Vintage Books.

13 Tomura, Masahiro 1990, Sokuinorei to daijôsai o yomu (Interpreting the Sokuinorei and the Daijôsai), Tokyo, Nihon Kirisutokyôdan Shuppankyoku, pp. 169-70.

14 The legal precedent of social consensus has had ongoing and wider implications in Japanese law. The most recent use has been in amendments to Japan's Labor Standards Law which passed through parliament on 27 June 2003. Under the revised legislation, dismissal of an employee will be deemed void if it is considered out of line with socially accepted norms of punitive treatment proportionate to the employee's misconduct. See Baker and McKenzie 2003-04, Asia Pacific Legal Developments Bulletin, vol. 18, no. 4, December 2003/January 2004, p. 12.

15 Ramseyer, Robert 1992, 'When Society Itself is the Tyrant', Japan Christian Review, no. 58.

16 Ramseyer, 1992, p. 78.

17 Kumazawa, Yoshinobu and David L. Swain (eds) 1991, Christianity in Japan, 1971-90, Tokyo, Kyo Bun Kwan (The Christian Literature Society in Japan), p. 65.

18 Kumazawa and Swain (eds) 1991, p. 66.

19 See Tomura, 1990, p. 167.

20 Kenpô o mamoru kirisutosha no kai.

21 Hirayama, Shôji 1988, 'Kenpô o mamoru kirisutosha no kai' ('Christians For Defence of the Constitution'), Nihon kirisutokyô daijiten (Encyclopedia of Japanese Christian History), Tokyo, Kyôbunkan, p. 494.

22 Kagawa was appointed advisor by Prime Minister Prince Higashikuni immediately after the war, and was influential in having September 1945 declared a month of penitence.

23 Sherrill, Michael J. 2001, The Protestant Church and Japanese Society: 1950-2000, Tokyo, Kirisutokyo.com, p. 9.

24 Mombushô (Ministry of Education) 1927, Ishin igo ni okeru kirisutokyô ni taisuru toriatsukai no hensen o joshi, kirisutokyô jogairon o bakusu (A Description of the Vicissitudes in the Treatment of Christianity Since the Restoration and a Refutation of the Theory of Christian Exception), Tokyo, Mombushô Shûkyôkyoku (Ministry of Education Religions Bureau), p. 1.

25 The bill consisted of 54 clauses covering such matters as requirements for registration of religious organisations and acceptable religious activities. It was the subject of 48 amendments before being put to the parliament in February 1900. The bill was defeated, partly due to Christian responses to the draft legislation.

26 Heihachiro Izawa 1988, 'Naimu shôrei daiyonjûichigo' ('Home Ministry Ordinance No. 41'), Nihon kirisutokyô daijiten (Encyclopedia of Japanese Christian History), Tokyo, Kyôbunkan, p. 972.

27 Dohi and Tomura (eds) 1988, pp.132-3.

28 Dohi and Tomura (eds) 1988, pp.134-45.

29 Dohi and Tomura (eds) 1988, p.134.

30 Dohi and Tomura (eds) 1988, p.135

31 Dohi and Tomura (eds) 1988, p.140. 
32 Dohi and Tomura (eds) 1988, p.148.

33 The Tokyo Asahi Shimbun ran a critical editorial on 14 February 1929 headed 'Reincarnation of the Religions Bill' while the Kokumin Shimbun of 17 February called it a 'retabling' of the Wakatsuki bill 'with minor amendments' and ran an article on 20 February entitled 'A wolf in sheep's clothing'. The Hôchi Shimbun of 19 February called it 'self-defeating' and on the following day warned that there was 'no room for optimism about the Religious Bodies Act - it won't get through parliament easily, and amendments are inevitable. See Nihon Kirisutokyô Tai Shûkyôdantaihôan Tokubetsu Iinkai (Japanese Christian Ad Hoc Committee on the Religious Bodies Bill) (eds) 1929, Shûkyôdantaihôan ni taisuru shodaishimbun no shasetsu (Editorials of major newspapers relating to the Religious Bodies Bill) Tokyo, no publisher.

34 Mombushô (Ministry of Education) 1927, pp. 4-5.

35 Mombushô (Ministry of Education) 1927, p. 4.

36 Uchimura, Kanzô 1927, Shûkyô hôan ni tsuite (Regarding the Religions Bill), Tokyo, no publisher, p. 1.

37 Nihon Kirisutokyô Tai Shûkyôdantaihôan Tokubetsu Iinkai.

38 See Yamamoto, Hideteru 1929, Shûkyô dantai hôan hantai kankei shiryô 'Kirisuto shinkyô no tasû wa hantai' (Materials Relating to the Opposition to the Religious Bodies Bill: Majority of Protestants Oppose Bill), Tokyo, Nihon Kirisutokyô Tai Shûkyôdantaihôan Tokubetsu Iinkai (Japanese Christian Ad Hoc Committee on the Religious Bodies Bill).

39 See Yamamoto, 1929. Significantly, two of the denominations with the largest number of objectors to the bill were the Salvation Army and the Holiness Church, both of which suffered the worst repression during World War II because of their continued opposition to government initiatives.

40 Bukkyô Rengokai Honbu (Buddhist Federation Headquarters) 1933, Shû kyôhô no hitsuyô naru riŷu (Reasons Why A Religious Law is Necessary), Tokyo, Bukkyô Rengokai Honbu (Buddhist Federation Headquarters), p. 2.

41 Sasahara, Yoshimitsu 1988, 'Shûkyô dantaihô' (Religious Bodies Law) in Nihon kirisutokyô daijiten (Encyclopedia of Japanese Christian History), Tokyo, Kyôbunkan, p. 650.

42 Sasahara, 1988.

43 Minato, Akiko 1962, Kirisutosha to Kokka (Christians and the State), Tokyo, Seisho tosho kankôkai, p. 125.

44 Furuya, Yasuo (ed.) 1997, A History of Japanese Theology, Grand Rapids, William B. Eerdmans.

45 The result exemplifies the notion of Christ-against-culture spelt out by H. Richard Niebuhr in his classic 1951 work Christ and Culture (New York, Harper). This is the description which best fits the dominant Protestant attitude to Japanese culture right throughout the modern period. For a useful monograph-length discussion of the way in which Christian identity is formed, see Tanner, Kathryn 1997, Theories of Culture: A New Agenda for Theology, Minneapolis, Augsburg Fortress. 